\title{
Leaflet Disruption Due To Host Tissue Overgrowth
}

National Cancer Institute

\section{Source}

National Cancer Institute. Leaflet Disruption Due To Host Tissue Overgrowth. NCI

Thesaurus. Code C50906.

The disturbance of a cusp of a heart valve secondary to an increase in tissue mass at the valve site, which can lead to valve dysfunction. This often happens as a result of fibrosis of tissue surrounding the suture line of a prosthetic valve. 